\title{
Spiritual Consolation from Nature ---- Exploration of Poetry Creation Principles of Daffodils
}

\author{
Hua Yang ${ }^{1, a}$, Ruiyun Zeng ${ }^{2, b}$ \\ ${ }^{1}$ College of Foreign Studies, Guilin University of Electronic Technology, Guilin, Guangxi, China \\ ${ }^{2}$ College of Foreign Studies, Guilin University of Electronic Technology, Guilin, Guangxi, China
}

Keywords: daffodils; William Wordsworth; language feature; spiritual consolation; nature

\begin{abstract}
The Daffodils is the masterpiece of an English Romantic poet, William Wordsworth. It describes natural landscapes and feelings of Wordsworth in the natural scenery. It also reflects the search and pursuit for the freedom of mind and the liberation of man. The worship of nature, rich imagination and simplicity and purity of the language are three main poetry creation principles of Daffodils.
\end{abstract}

\section{Introduction}

The Daffodils was created by William Wordsworth in 1804. Wordsworth (1770-1850) was one of the greatest poets in English literature in the 19th century and the most influential poet in the history of western literature. He broke through the Neoclassicism in 18th century, using the "poetic language" to depict the shackles of the upper class, and led the English poetry to become colloquial and civilian. With his smooth, clear, simple style and bold innovation, he led the English poetry world into a new era. ${ }^{[1]}$

Wordsworth was a passionate lover of nature and his poems are famous for singing highly of nature and natural beauty. His descriptions of lakes and rivers, of meadows and woods, of skies and clouds are exquisite. Wordsworth always thought that all the good poetry should come from spontaneous overflow of powerful feeling. In most of his poem, on the one hand, Wordsworth usually compared the natural scenery with the noisiness of city and the ugliness of reality. In this way, he could release his dissatisfaction to the society. On the other hand, Wordsworth mixed his love to the nature and his sadness to the society together, and put his heart to natural scenery in order to exchange some spiritual comfort from nature.

Daffodil was written in 1804 and published in 1807. According to Wordsworth's sister Dorothy, in her diary of April 15, 1802, they returned to see some of the daffodils in the woods of the park. About two years later, Wordsworth wrote the poem based on his memory and collected Poems into his poetry collection Poems of the Imagination. The Daffodils authentically describes the beautiful scenery Wordsworth and his younger sister saw. On that day they enjoyed: the golden, fluttering and dancing daffodils; the sparking waves; the sunshine; the trees; the trees; the lake. All of these made Wordsworth and his younger sister linger around for a long time and nearly forgot to return. Therefore, this poem is an exalted poem of nature.

The poem goes:

\section{Wandered Lonely as a Cloud}

I wandered lonely as a cloud

That floats on high o'er vales and hills,

When all at once I saw a crowd,

A host, of golden daffodils;

Beside the lake, beneath the trees,

Fluttering and dancing in the breeze.

Continuous as the stars that shine

And twinkle on the milky way,

They stretched in never-ending line
Along the margin of a bay:

Ten thousand saw I at a glance,

Tossing their heads in sprightly dance.

The waves beside them danced; but they

Out-did the sparkling waves in glee:

A poet could not but be gay,

In such a jocund company:

I gazed --- and gazed --- but little thought

What wealth the show to me had brought: 
For oft, when on my couch I lie

In vacant or in pensive mood,

They flash upon that inward eye

In Daffodils, according to poet's description, we know Wordsworth himself got the great comfort from the beautiful natural scenery. So Daffodils fully embodies the poet's love for nature and Wordsworth's famous creation idea for poem, that is, the good poetry should come from spontaneous overflow of powerful feeling which is reflected in silence. According to the above, this paper attempts to analyze the poetry creation principles reflected in this short poem from the following three aspects: the worship of nature, rich imagination and simplicity and purity of the language.

\section{Worship of nature}

When Wordsworth was alive, he enjoyed communicate with nature and walking alone under the quiet stars or in the valley of the lakes. ${ }^{[3]}$ He regarded nature as his spiritual home. For him, nature is the source of his strength and knowledge. Nature is a semi-anthropomorphic force that extends to people and has healing functions. ${ }^{[1]}$

The first stanza of the poem is mainly about charming natural scenery. At the beginning, the poet was wandering in the valley and suddenly he told us "at once I saw a crowd, a host, of golden daffodils". It seems that the poet found something which made his eyes sparkled ---- daffodils. The words, such as "golden daffodils", "beside the lake”, "beneath the trees", "fluttering”, "dancing”, "in the breeze", make us imagine the beautiful view and arouse the readers' visual aesthetic feeling. All these beautiful views made the poet marvel at the nature and brought the poet great spiritual consolation besides loneliness. Meanwhile, the words "lake", "trees", "breeze" are all related to life. And "fluttering", "dancing" are both related to the vigor of life. It reflected the poet sought brightness and hope from the nature. All these vivid landscapes illustrate Wordsworth' worship of nature.

In other words, nature can purify a person's heart, and it has the healing function of soothing lonely heart. In the first line, Wordsworth said “I wander'd lonely as a cloud that float on high o'er values and hills" ${ }^{[2]}$. We feel a strong sense of melancholy and loneliness. Such feelings for romantic poets had a strong relationship with their lonely character and their thinking to the society and the life. Under such social circumstance, Wordsworth wanted to use this sentence to show his melancholy to the society and his worries to people's future.

Therefore, daffodils here symbolize the regeneration of the poet's spirit. To be more specific, the joy of nature has allowed the poet to immerse himself in the beauty and purify his soul. The poet believes in the purifying of nature, so he eulogizes nature and worships the nature, trying to purify the human soul by the noble things of nature, and then eliminate the darkness and the ugliness of the world. ${ }^{[4]}$

\section{Rich imagination}

In 1798, Wordsworth published a collection of poems together Lyrical Ballads. When the book was republished in 1800, Wordsworth wrote a preface with the lines that "all good poetry is the natural expression of strong feelings, and it comes from the emotions accumulated in tranquility" ${ }^{[5]}$. In the preface, he also said that in these poems, his aim was to choose the incidents and situations from common life, from beginning to end, to choose the language really informed by men to narrate and describe them. At the same time, give them the color of their imagination, so that ordinary things can be presented in unusual ways in front of the man. So imagination plays an important role in Wordsworth's poetry creation. ${ }^{[6]}$

In Daffodils, Wordsworth gives readers a vivid description of nature with imaginary words through recalling what he saw a few years ago. Wordsworth, in the poem, employs figurative language to evoke not only the visual effect but also the emotional response. In line 1, the poet makes a comparison between "I wandered lonely" and "a cloud" by the use of simile, thus conveys 
to us his lonely and melancholy mood with the image of "cloud". In line 7, he also amplifies the visual effect by the use of another simile "Continuous as the stars that shine..." to evoke our sense of "daffodils" with the image of "stars" twinkling on the milky way which is familiar to us all. He goes further to impress us with the image of countless daffodils with an overstatement in line 9 “They stretched in never-ending line". Besides, natural things are also endowed with human being's characters by the poet's subtle use of personification. For example, "Tossing their heads in sprightly dance" "The waves beside them danced" therefore, as we read the poem, we become aware of the poet's deep love toward nature through his lovely and vivid description about natural things with his figurative and imaginary language.

And at the meanwhile, the poet compares daffodils to stars in order to imply the spiritual instruction function of the daffodils. Because the stars can give people the light, guide the road for the people in the darkness and bring people hope. The daffodils like the stars also gave the poet the light and the hope and even the consolation.

\section{Simplicity and purity of language}

Simplicity and purity of the language is another feature of Wordsworth's poetry. In the preface, he has told us "his aim is to choose the language really informed by men to narrate and describe them. At the same time, give them the color of their imagination, so that ordinary things can be presented in unusual ways in front of the man." ${ }^{[5]}$ Wordsworth advocates the selection of ordinary things and the use of pure and simple language.

First, the poem is based on something very common, and Wordsworth creates a brilliant lyric poem inspired by the very common plant. He was impressed by the sight of daffodils on the outskirts of the countryside, as he was returning from his visit to his friend's home. Two years later, he recalled the memory of that time, and created Daffodils. ${ }^{[7]}$

Then, most of the languages used in daffodils are very colloquial language. According to the statistics of Yuan Xianjun, "the poem has totally 152 English words. With only five times three syllable word repeated, the rest are all the commonly used single syllable and double syllables words. Among them, only three words are written words, and the rest are all spoken words." ${ }^{[8]}$ In addition, the word order and sentence patterns in the poem are simple and clear, not obscure. These simple words and sentence patterns are as natural and smooth as the clouds floating in the sky, expressing the poet's feelings and thoughts in a very direct way.

From the above, in Daffodils, Wordsworth embodies his emotions in the landscape of his works, and uses the expression of folk language to express his works. The use of such pure and simple language brings infinite vitality and charm to the works.

\section{Conclusions}

To sum up, although Daffodils is short, the poem fully demonstrates the poetic theory and creative talent of poet William Wordsworth. The worship of nature, rich imagination and simplicity and purity of the language are the most prominent principles in Wordsworth's poetry creation. At the same time, in this poem, the poet's happy mood and consolation comes from the natural and ordinary situation of the dancing daffodils. We marvel at the power of nature again. Nature can have subtle influence on a person's mind. As staying with nature, a depressed man can recover from his melancholy gradually. Nature always stays in peace. Nature can radiate soft light that lighten people's hearts and dispels the sorrow. ${ }^{[9]}$ Nature not only has aesthetic value, but also has spiritual consolation value.

\section{References}

[1] Zhang Boxiang, Selected Readings in English and American Literature [M]. Beijing: Foreign Language Teaching and Research Press, 1999.

[2] Wu Weiren, History and Anthology of English Literature, [M]. Foreign language Teaching and 
Research Press, 1988.

[3] $\mathrm{Xu} \mathrm{Li}$, Poetics of Romanticism in Wordsworth's The Daffodils, [J]. Journal of Anhui University of Technology (Social Sciences), Vol.32, No.1, 2015.

[4] Jiang Wei, Analysis on the Solitary Reaper and The Daffodils, [J]. Journal of Zhengzhou Institute of Aeronautical Industry Management (Social Science Edition), No. 2, 2005.

[5] Wordsworth, William. Preface to Lyrica l Ballads, With Pastoral and Other Poems. In The Norton Anthology of English Literature, [M]. New York: Norton, 1986.

[6] Mahoney. L. J., Wordsworth and the Critics, [M]. New York: Camden House, 2001.

[7] Su Baoying, Poetry Language Features of English Poet William Wordsworth, [J]. Language Planning, No. 1, 2016.

[8] Yuan Xianjun, William Wordsworth' Daffodils and Poetic language, [J]. Journal of Beijing International Studies University, Vol.132, No.2, 2006.

[9] Jiang Yuan, I Appreciate “I Wandered Lonely as A Cloud” from the perspective of Semantics, [J]. Thinking, Vol.36, No. A1, 2010. 